\title{
Brevundimonas terrae sp. nov., isolated from an alkaline soil in Korea
}

Correspondence

Jung-Hoon Yoon

jhyoon@kribb.re.kr

\author{
Jung-Hoon Yoon, So-Jung Kang, Jung-Sook Lee and Tae-Kwang Oh \\ Korea Research Institute of Bioscience and Biotechnology (KRIBB), PO Box 115, Yusong, \\ Taejon, Korea
}

\begin{abstract}
A Gram-negative, rod-shaped, Brevundimonas-like bacterial strain, $\mathrm{KSL}-145^{\top}$, was isolated from an alkaline soil in Korea and subjected to a polyphasic taxonomic investigation. Strain KSL-145 grew optimally at $\mathrm{pH} 7 \cdot 5-8 \cdot 0$ and $30^{\circ} \mathrm{C}$ without $\mathrm{NaCl}$. It was characterized chemotaxonomically as containing $\mathrm{Q}-10$ as the predominant ubiquinone and $\mathrm{C}_{18: 1} \omega 7 \mathrm{c}$ and $\mathrm{C}_{16: 0}$ as the major fatty acids. The DNA G $+\mathrm{C}$ content was $61 \cdot 8 \mathrm{~mol} \%$. A phylogenetic analysis based on $16 \mathrm{~S}$ rRNA gene sequences showed that strain $\mathrm{KSL}-145^{\top}$ fell within the radiation of the cluster comprising Brevundimonas species and Mycoplana bullata. The levels of 16S rRNA gene sequence similarity between strain KSL-145 ${ }^{\top}$ and the type strains of Brevundimonas species and M. bullata ranged from $95 \cdot 3$ to $98 \cdot 7 \%$. The mean DNA-DNA relatedness values between strain KSL- $145^{\top}$ and the type strains of Brevundimonas diminuta and $M$. bullata, the closest phylogenetic relatives, were 26 and $15 \%$, respectively. Strain KSL-145 ${ }^{\top}$ could be differentiated from Brevundimonas species and $M$. bullata by differences in several phenotypic characteristics. On the basis of the phenotypic, phylogenetic and genetic data, strain $\mathrm{KSL}-145^{\top}$ represents a novel species in the genus Brevundimonas, for which the name Brevundimonas terrae sp. nov. is proposed. The type strain is KSL-145 ${ }^{\top}\left(=\right.$ KCTC $12481^{\top}=$ JCM $\left.13476^{\top}\right)$.
\end{abstract}

The genus Brevundimonas was proposed through the reclassification of two Pseudomonas species as Brevundimonas diminuta and Brevundimonas vesicularis (Segers et al., 1994). At the time of writing, the genus comprises 11 species with validly published names: $B$. diminuta and B. vesicularis (Segers et al., 1994), B. alba, B. aurantiaca, B. bacteroides, B. intermedia, B. subvibrioides and B. variabilis (Abraham et al., 1999), B. nasdae (Li et al., 2004), B. mediterranea (Fritz et al., 2005) and B. kwangchunensis (Yoon et al., 2006). In this study, we report on the taxonomic characterization of a Brevundimonas-like bacterial strain, $\mathrm{KSL}-145^{\mathrm{T}}$, isolated from an alkaline soil (approximate $\mathrm{pH} 9 \cdot 0-10 \cdot 0)$ in Korea.

Strain KSL- $145^{\mathrm{T}}$ was isolated using the standard dilution plating technique at $30^{\circ} \mathrm{C}$ on $10 \times$ diluted nutrient agar (Difco) adjusted to $\mathrm{pH} 10 \cdot 0$. B. diminuta LMG $2089^{\mathrm{T}}$, which was used as a reference strain for DNA-DNA hybridization, was obtained from the Laboratorium voor Microbiologie, Universiteit Gent (Ghent, Belgium). Mycoplana bullata DSM $7126^{\mathrm{T}}$, which was used as a reference strain for DNA-DNA hybridization and phenotypic characterization, was obtained

The GenBank/EMBL/DDBJ accession number for the 16S rRNA gene sequence of strain $\mathrm{KSL}-145^{\top}$ is DO335215.

Biolog assimilation data and cellular fatty acid compositions for strain $\mathrm{KSL}-145^{\top}$ and related taxa are available as supplementary material in IJSEM Online. from the Deutsche Sammlung von Mikroorganismen und Zellkulturen (Braunschweig, Germany). The cell morphology was examined using light microscopy (E600; Nikon) and transmission electron microscopy. The presence of flagella was determined by transmission electron microscopy using cells from exponentially growing cultures. For the transmission electron microscopic observation, the cells were negatively stained with $1 \%(\mathrm{w} / \mathrm{v})$ phosphotungstic acid and the grids were examined (after air-drying) with a Philips CM-20 transmission electron microscope. The Gram reaction was determined using the bioMérieux Gram-stain kit according to the manufacturer's instructions. Growth at various temperatures $\left(4-40{ }^{\circ} \mathrm{C}\right)$ was measured on trypticase soy agar (TSA; Difco). Growth in the absence of $\mathrm{NaCl}$ was investigated in trypticase soy broth prepared according to the formula of the Difco medium except that no $\mathrm{NaCl}$ was used. Growth at various $\mathrm{NaCl}$ concentrations $(0.5 \%$, w/v, and $1 \cdot 0-5 \cdot 0 \%, \mathrm{w} / \mathrm{v}$, using increments of $1 \cdot 0 \%)$ was investigated in trypticase soy broth (Difco). The $\mathrm{pH}$ range for growth was determined in nutrient broth (Difco) adjusted to various $\mathrm{pH}$ values (initial $\mathrm{pH} 4 \cdot 5-10 \cdot 5$, using increments of $0.5 \mathrm{pH}$ units), prior to sterilization, by the addition of $\mathrm{HCl}$ or $\mathrm{Na}_{2} \mathrm{CO}_{3}$. Growth under anaerobic conditions was determined after incubation in an anaerobic chamber on TSA and on TSA supplemented with nitrate, both of which had been prepared anaerobically using nitrogen. Catalase and oxidase activities and the hydrolysis of casein, gelatin, hypoxanthine, starch, Tweens 20, 40, 60 and 80, tyrosine, 
urea and xanthine were determined as described by Cowan \& Steel (1965). The hydrolysis of aesculin and the reduction of nitrate were studied as described previously (Lanyi, 1987). The assimilation of various substrates was determined by using the Biolog GN2 MicroPlate assay as recommended by the manufacturers. Sensitivity to antibiotics was tested on TSA plates, using antibiotic discs containing the following amounts ( $\mu \mathrm{g}$, unless otherwise indicated): polymyxin $\mathrm{B}$, $100 \mathrm{U}$; streptomycin, 50; penicillin G, 20 U; chloramphenicol, 100; ampicillin, 10; cephalothin, 30; gentamicin, 30; novobiocin, 5; tetracycline, 30; kanamycin, 30; lincomycin, 15; oleandomycin, 15; neomycin, 30; and carbenicillin, 100. Enzyme activity was determined by using the API ZYM system (bioMérieux). Other physiological and biochemical tests were performed with the API 20E system (bioMérieux).

Cell biomass for DNA extraction and for isoprenoid quinone analysis was obtained from cultivation in trypticase soy broth at $30^{\circ} \mathrm{C}$. Chromosomal DNA was isolated and purified according to the method described by Yoon et al. (1996), with the exception that RNase T1 was used in combination with RNase A to minimize contamination with RNA. The 16S rRNA gene was amplified by performing a PCR with two universal primers as described previously (Yoon et al., 1998). The sequencing of the amplified 16S rRNA gene and the phylogenetic analysis were performed as described by Yoon et al. (2003). Isoprenoid quinones were extracted according to the method of Komagata \& Suzuki (1987) and analysed using reversed-phase HPLC and a YMC ODS-A $(250 \times 4.6 \mathrm{~mm})$ column. For fatty acid analysis, cell mass of strain KSL- $145^{\mathrm{T}}$ was harvested from TSA plates after incubation for 3 days at $30^{\circ} \mathrm{C}$. The fatty acids were extracted and the fatty acid methyl esters prepared according to the standard protocol of the MIDI/Hewlett Packard Microbial Identification System (Sasser, 1990). The DNA G+C content was determined by using the method of Tamaoka \& Komagata (1984), with the modification that DNA was hydrolysed and the resultant nucleotides were analysed by reversed-phase HPLC. DNA-DNA hybridization was performed fluorometrically by the method of Ezaki et al. (1989) using photobiotin-labelled DNA probes and microdilution wells. Five replicate hybridizations were performed for each sample. The highest and lowest values obtained for each sample were excluded and the means of the remaining three values were quoted as DNA-DNA relatedness values.

The morphological, cultural, physiological and biochemical characteristics of strain KSL-145 ${ }^{\mathrm{T}}$ are given in the species description (see below) or are shown in Table 1 or Supplementary Table S1 (available in IJSEM Online). The almost-complete 16S rRNA gene sequence of strain KSL$145^{\mathrm{T}}$ determined in this study comprised $1418 \mathrm{nt}$, representing approximately $96 \%$ of the Escherichia coli $16 \mathrm{~S}$ rRNA gene sequence. The $16 \mathrm{~S}$ rRNA gene sequence analyses showed that strain KSL- $145^{\mathrm{T}}$ is phylogenetically most closely related to Brevundimonas species and M. bullata (Fig. 1). In the phylogenetic tree based on the neighbour-joining algorithm, strain KSL- $145^{\mathrm{T}}$ joined the type strain of $B$. diminuta at a bootstrap confidence value of $99 \cdot 8 \%$, and this cluster joined the type strain of M. bullata at a bootstrap confidence value of $95.6 \%$ (Fig. 1). The relationship between the cluster comprising strain $\mathrm{KSL}-145^{\mathrm{T}}$, Brevundimonas species and M. bullata and the cluster comprising Caulobacter species was supported by a relatively high bootstrap resampling value $(79.0 \%)$ (Fig. 1). Strain KSL- $145^{\mathrm{T}}$ exhibited $16 \mathrm{~S}$ rRNA gene sequence similarity values of 98.7 and $98.0 \%$ with respect to $B$. diminuta LMG $2089^{\mathrm{T}}$ and M. bullata IAM $13153^{\mathrm{T}}$, respectively, and values of $95 \cdot 3-96 \cdot 9 \%$ with respect to the other Brevundimonas species. The sequence similarities with respect to all other species included in the phylogenetic analysis were below $94.9 \%$ (Fig. 1).

The results obtained from chemotaxonomic analyses were consistent with the results of 16S rRNA gene sequence analysis. The predominant isoprenoid quinone detected in strain KSL- $145^{\mathrm{T}}$ was Q-10, at a peak-area ratio of approximately $86 \%$; a minor amount of Q-8 (approx. $9 \%)$ was also present. This predominant ubiquinone type was the same as those of Brevundimonas species (Segers et al., 1994; Abraham et al., 1999; Li et al., 2004; Fritz et al., 2005; Yoon et al., 2006). The major fatty acids in strain KSL$145^{\mathrm{T}}$ were $\mathrm{C}_{18: 1} \omega 7 c$ and $\mathrm{C}_{16: 0}$. This fatty acid profile was similar to those of Brevundimonas species (Abraham et al., 1999; Li et al., 2004; Fritz et al., 2005) (see Supplementary Table S2 available in IJSEM Online). The DNA G+C content of strain KSL- $145^{\mathrm{T}}$ was $61 \cdot 8 \mathrm{~mol} \%$, which is rather lower than those of recognized Brevundimonas species (Table 1).

Strain KSL- $145^{\mathrm{T}}$ exhibited mean DNA-DNA relatedness levels of 26 and $15 \%$ with respect to B. diminuta LMG $2089^{\mathrm{T}}$ and M. bullata DSM $7126^{\mathrm{T}}$, respectively, strains that showed 16S rRNA gene sequence similarity values of more than $97 \%$ to strain KSL- $145^{\mathrm{T}}$. This value indicates that strain KSL$145^{\mathrm{T}}$ is a member of a genomic species that differs from $B$. diminuta and M. bullata (Wayne et al., 1987). Strain KSL$145^{\mathrm{T}}$ differed from the other Brevundimonas species, as well as from $B$. diminuta and M. bullata, in terms of several phenotypic characteristics (Table 1). The phylogenetic and genetic distinctiveness and differential phenotypic properties were sufficient to categorize strain KSL-145 ${ }^{\mathrm{T}}$ as a member of a species that is distinct from previously recognized Brevundimonas species and from M. bullata (Wayne et al., 1987; Stackebrandt \& Goebel, 1994). In the phylogenetic tree based on $16 \mathrm{~S}$ rRNA gene sequences, $M$. bullata was more closely related to the genus Brevundimonas than to the clade comprising Mycoplana dimorpha, the type species of the genus Mycoplana. M. bullata may have to be reclassified as a member of another genus - perhaps the genus Brevundimonas - but such reclassification might not be appropriate at this time. Therefore, on the basis of the data presented, strain KSL- $145^{\mathrm{T}}$ should be classified within the genus Brevundimonas as a member of a novel species, for which the name Brevundimonas terrae sp. nov. is proposed. 
Table 1. Differential phenotypic characteristics of strain $\mathrm{KSL}-145^{\top}$, Brevundimonas species and M. bullata

Taxa: 1, strain KSL-145 ; 2, B. kwangchunensis (data from Yoon et al., 2006); 3, B. diminuta (Palleroni, 1984; Segers et al., 1994; Li et al., 2004); 4, B. vesicularis (Palleroni, 1984; Segers et al., 1994; Li et al., 2004); 5, B. alba (Poindexter, 1964); 6, B. aurantiaca (Poindexter, 1964; Li et al., 2004); 7, B. bacteroides (Poindexter, 1964); 8, B. intermedia (Poindexter, 1964; Li et al., 2004); 9, B. subvibrioides (Poindexter, 1964); 10, B. variabilis (Poindexter, 1964); 11, B. nasdae (Li et al., 2004); 12, B. mediterranea (Fritz et al., 2005); 13, M. bullata (unless indicated, data from Urakami et al., 1990). Symbols: +, positive; -, negative; ND, no data available; W, weakly positive; V, variable; NG, no growth. Data in parentheses are for the type strain.

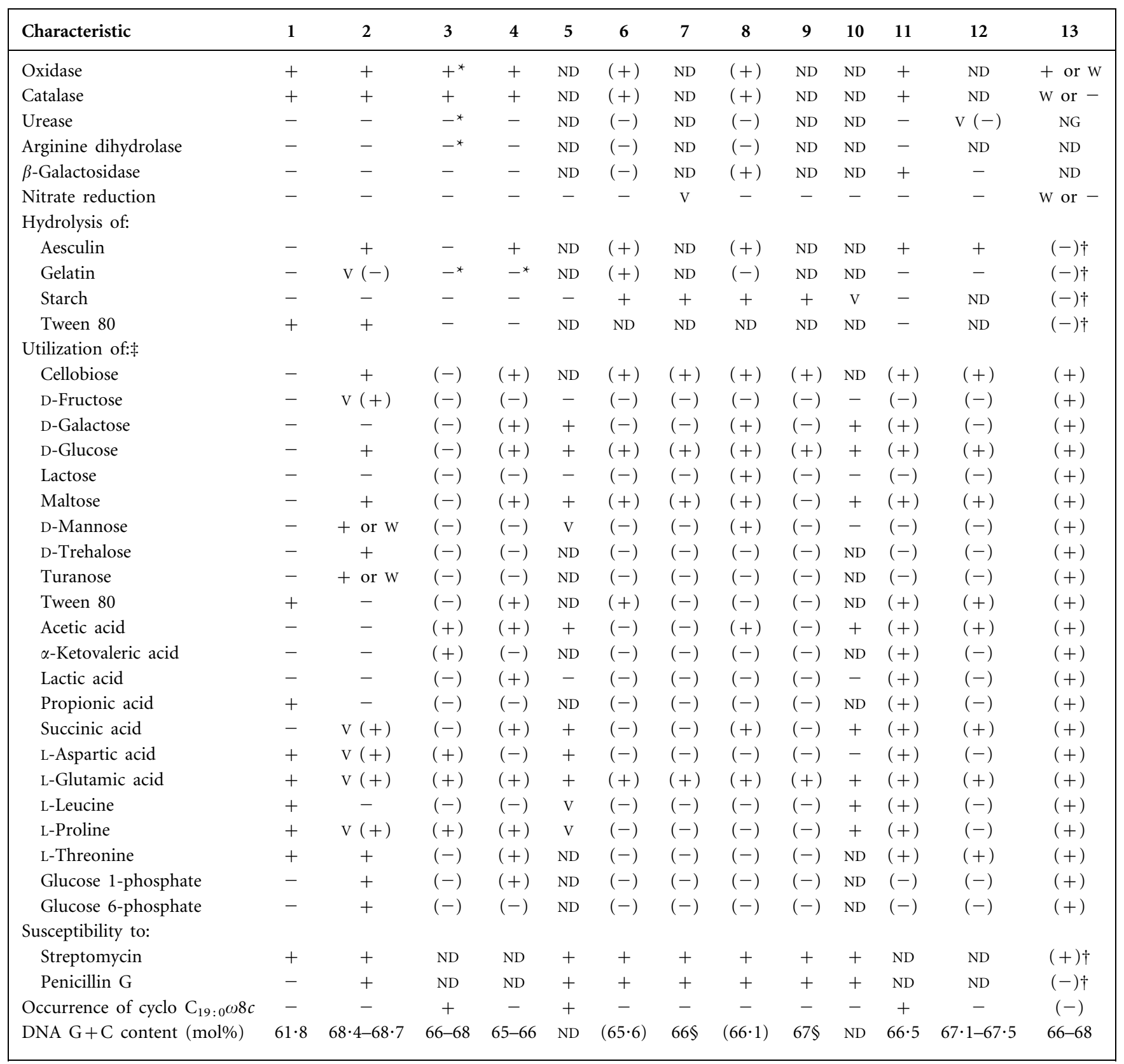

${ }^{*}$ Result reported by Palleroni (1984) and Segers et al. (1994); different result for the type strain obtained by Li et al. (2004).

$\dagger$ Data from this study.

$\ddagger$ Data from Biolog GN2 MicroPlate assay taken from Yoon et al. (2006); data for M. bullata taken from this study for the type strain; data for B. alba and B. variabilis taken from Poindexter (1964).

$\S$ Determined for one isolate by Poindexter (1989). 


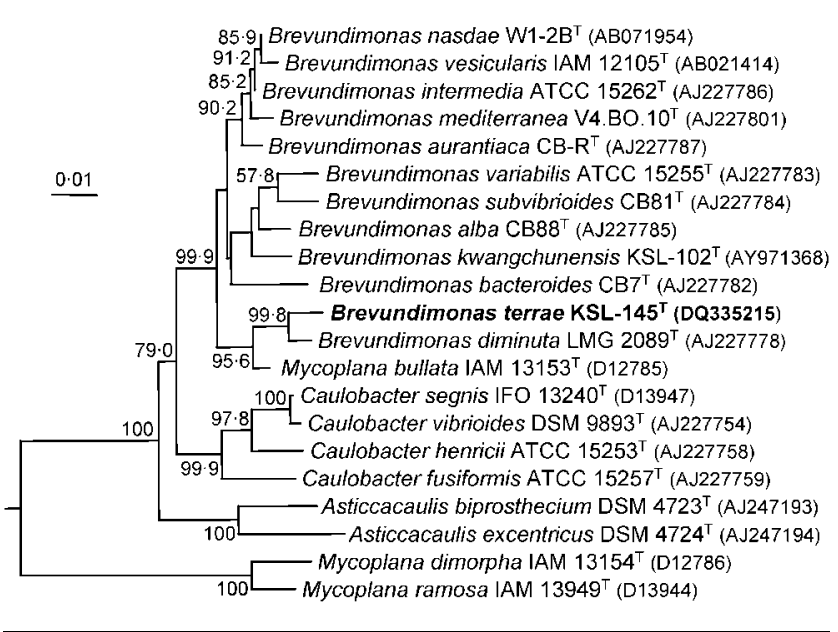

Fig. 1. Neighbour-joining phylogenetic tree, based on $16 \mathrm{~S}$ rRNA gene sequences, showing the positions of strain KSL$145^{\top}$, Brevundimonas species and some other related taxa. Bootstrap values (expressed as percentages of 1000 replications) $>50 \%$ are shown at branch points. Rhodospirillum rubrum ATCC $11170^{\top}$ was used as an outgroup (not shown). Bar, $0 \cdot 01$ substitutions per nucleotide position.

\section{Description of Brevundimonas terrae sp. nov.}

Brevundimonas terrae (ter'rae. L. gen. n. terrae of the soil).

Cells are Gram-negative, aerobic rods $(0 \cdot 4-0 \cdot 6$ $\times 1 \cdot 0-3 \cdot 0 \mu \mathrm{m})$. Motile by means of a single polar flagellum. Colonies on TSA are circular, smooth, glistening, slightly convex, greyish-yellow in colour and $2 \cdot 0-3 \cdot 0 \mathrm{~mm}$ in diameter after 3 days incubation at $30{ }^{\circ} \mathrm{C}$. Optimal temperature for growth is $30^{\circ} \mathrm{C}$; growth occurs at 4 and $37^{\circ} \mathrm{C}$, but not at $38^{\circ} \mathrm{C}$. Optimal pH for growth is between $7 \cdot 5$ and $8 \cdot 0$; growth occurs at $\mathrm{pH} 6.5$ and $10 \cdot 0$, but not at $\mathrm{pH} 6 \cdot 0$ or $10 \cdot 5$. Growth occurs in the presence of $0-2 \%$ (w/v) NaCl; optimal growth occurs without $\mathrm{NaCl}$. Anaerobic growth does not occur on TSA or on TSA supplemented with nitrate. Casein and Tweens 20, 40 and 60 are hydrolysed, but hypoxanthine, xanthine and tyrosine are not. $\mathrm{H}_{2} \mathrm{~S}$ and indole are not produced. Lysine decarboxylase, ornithine decarboxylase and tryptophan deaminase are absent. In assays with the API ZYM system, alkaline phosphatase, esterase (C4), esterase lipase (C8), leucine arylamidase, trypsin, $\alpha$-chymotrypsin, acid phosphatase and naphthol-AS-BI-phosphohydrolase are present, but lipase (C14), valine arylamidase, cystine arylamidase, $\alpha$-galactosidase, $\beta$-glucuronidase, $\alpha$-glucosidase, $\beta$-glucosidase, $N$ acetyl- $\beta$-glucosaminidase, $\alpha$-mannosidase and $\alpha$-fucosidase are absent. Susceptible to polymyxin B, chloramphenicol, gentamicin, novobiocin, tetracycline, kanamycin, oleandomycin and neomycin, but not to ampicillin, cephalothin, lincomycin or carbenicillin. The predominant ubiquinone is Q-10. The major fatty acids are $\mathrm{C}_{18: 1} \omega 7 c$ and $\mathrm{C}_{16: 0}$. The DNA G $+\mathrm{C}$ content is $61.8 \mathrm{~mol} \%$ (determined by HPLC). Other phenotypic characteristics are given in Table 1 and Supplementary Table S1.
The type strain, KSL-145 ${ }^{\mathrm{T}}\left(=\mathrm{KCTC} 12481^{\mathrm{T}}=\mathrm{JCM} 13476^{\mathrm{T}}\right)$, was isolated from an alkaline soil in Kwangchun, Korea.

\section{Acknowledgements}

This work was supported by the 21C Frontier Program of Microbial Genomics and Applications (grant MG05-0401-2-0) from the Ministry of Science and Technology (MOST) of the Republic of Korea.

\section{References}

Abraham, W.-R., Strömpl, C., Meyer, H. \& 8 other authors (1999). Phylogeny and polyphasic taxonomy of Caulobacter species. Proposal of Maricaulis gen. nov. with Maricaulis maris (Poindexter) comb. nov. as the type species, and emended description of the genera Brevundimonas and Caulobacter. Int J Syst Bacteriol 49, 1053-1073.

Cowan, S. T. \& Steel, K. J. (1965). Manual for the Identification of Medical Bacteria. London: Cambridge University Press.

Ezaki, T., Hashimoto, Y. \& Yabuuchi, E. (1989). Fluorometric deoxyribonucleic acid-deoxyribonucleic acid hybridization in microdilution wells as an alternative to membrane filter hybridization in which radioisotopes are used to determine genetic relatedness among bacterial strains. Int J Syst Bacteriol 39, 224-229.

Fritz, I., Strömpl, C., Nikitin, D. I., Lysenko, A. M. \& Abraham, W.-R. (2005). Brevundimonas mediterranea sp. nov., a non-stalked species from the Mediterranean Sea. Int J Syst Evol Microbiol 55, 479-486.

Komagata, K. \& Suzuki, K. (1987). Lipids and cell-wall analysis in bacterial systematics. Methods Microbiol 19, 161-203.

Lanyi, B. (1987). Classical and rapid identification methods for medically important bacteria. Methods Microbiol 19, 1-67.

Li, Y., Kawamura, Y., Fujiwara, N., Naka, T., Liu, H., Huang, X., Kobayashi, K. \& Ezaki, T. (2004). Sphingomonas yabuuchiae sp. nov. and Brevundimonas nasdae sp. nov., isolated from the Russian space laboratory Mir. Int J Syst Evol Microbiol 54, 819-825.

Palleroni, N. J. (1984). Genus Pseudomonas Migula 1894. In Bergey's Manual of Systematic Bacteriology, vol. 1, pp. 141-199. Edited by N. R. Krieg \& J. G. Holt. Baltimore: Williams \& Wilkins.

Poindexter, J. S. (1964). Biological properties and classification of the Caulobacter group. Bacteriol Rev 28, 231-295.

Poindexter, J. S. (1989). Genus Caulobacter Henrici and Johnson 1935. In Bergey's Manual of Systematic Bacteriology, vol. 3, pp. 1924-1939. Edited by J. T. Staley, M. P. Bryant, N. Pfennig \& J. G. Holt. Baltimore: Williams \& Wilkins.

Sasser, M. (1990). Identification of bacteria by gas chromatography of cellular fatty acids, Technical Note no. 101. Newark, DE: MIDI.

Segers, P., Vancanneyt, M., Pot, B., Torck, U., Hoste, B., Dewettinck, D., Falsen, E., Kersters, K. \& De Vos, P. (1994). Classification of Pseudomonas diminuta Leifson and Hugh 1954 and Pseudomonas vesicularis Büsing, Döll, and Freytag 1953 in Brevundimonas gen. nov. as Brevundimonas diminuta comb. nov. and Brevundimonas vesicularis comb. nov., respectively. Int J Syst Bacteriol 44, 499-510.

Stackebrandt, E. \& Goebel, B. M. (1994). Taxonomic note: a place for DNA-DNA reassociation and 16S rRNA sequence analysis in the present species definition in bacteriology. Int J Syst Bacteriol 44, 846-849.

Tamaoka, J. \& Komagata, K. (1984). Determination of DNA base composition by reverse-phase high-performance liquid chromatography. FEMS Microbiol Lett 25, 125-128.

Urakami, T., Oyanagi, H., Araki, H., Suzuki, K. \& Komagata, K. (1990). Recharacterization and emended description of the genus 
Mycoplana and description of two new species, Mycoplana ramosa and Mycoplana segnis. Int J Syst Bacteriol 40, 434-442.

Wayne, L. G., Brenner, D. J., Colwell, R. R. \& 9 other authors (1987). International Committee on Systematic Bacteriology. Report of the ad hoc committee on reconciliation of approaches to bacterial systematics. Int J Syst Bacteriol 37, 463-464.

Yoon, J.-H., Kim, H., Kim, S.-B., Kim, H.-J., Kim, W. Y., Lee, S. T., Goodfellow, M. \& Park, Y.-H. (1996). Identification of Saccharomonospora strains by the use of genomic DNA fragments and rRNA gene probes. Int J Syst Bacteriol 46, 502-505.
Yoon, J.-H., Lee, S. T. \& Park, Y.-H. (1998). Inter- and intraspecific phylogenetic analysis of the genus Nocardioides and related taxa based on $16 \mathrm{~S}$ rRNA gene sequences. Int J Syst Bacteriol 48, 187-194.

Yoon, J.-H., Kang, K. H. \& Park, Y.-H. (2003). Psychrobacter jeotgali sp. nov., isolated from jeotgal, a traditional Korean fermented seafood. Int J Syst Evol Microbiol 53, 449-454.

Yoon, J.-H., Kang, S.-J., Oh, H. W., Lee, J.-S. \& Oh, T.-K. (2006). Brevundimonas kwangchunensis sp. nov., isolated from an alkaline soil in Korea. Int J Syst Evol Microbiol 56, 613-617. 